\title{
Multi-Type FACTS Controllers for Power System Compensation: A Case Study of the Nigerian 48-Bus, 330 kV System
}

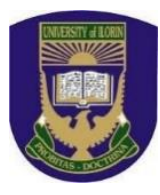

${ }^{1}$ Department of Electrical and Electronic Engineering, Akwa Ibom State University, Mkpat Enin, Nigeria ${ }^{2}$ Department of Electrical/Electronic Engineering, Michael Okpara University of Agriculture, Umudike,

Nigeria.

ABSTRACT: Flexible alternating current transmission system (FACTS) devices have provided proficient answers to power system instabilities faced in the systems operations today with very little infrastructural investment fund. This paper investigates the effects of the installation of the combination of two kinds of FACTS controllers; static VAR compensator (SVC) and thyristor controlled series compensator (TCSC) compared with the installation of SVC or TCSC alone in the system. Voltage magnitude profile, active and reactive power losses of the three scenarios were achieved in the Nigerian 48-bus power system network using power system analysis toolbox (PSAT) in MATLAB environment. Simulation results obtained without and with FACTS devices optimally placed using voltage stability sensitivity factor (VSSF), revealed that the percentage decrease of the net real and reactive power losses of the combined SVC and TCSC was the highest at $31.917 \%$ whereas that of the standalone SVC and TCSC stood at $19.769 \%$ and $30.863 \%$ respectively. This shows that in addition to their capabilities to maintain acceptable voltage profile, the combination of SVC and TCSC has better compensating effect as they mitigate against power losses which was observed in their high percentage decrease in power losses compared to the standalone FACTS devices.

KEYWORDS: FACTS, optimum location, PSAT, SVC, TCSC, VSSF

[Received Mar. 30, 2020; Revised Nov. 27, 2020; Accepted Feb. 01, 2021]

Print ISSN: 0189-9546 | Online ISSN: 2437-2110

\section{INTRODUCTION}

The ever growing population of electric energy consumers necessitates the expansion of electrical power systems as is the case in Nigeria (Nkan et al, 2019a). With the ongoing expansions and growth of the electric utility industry, including deregulation in Nigeria, numerous changes characterized by additional generating stations, increase in transmission lines and loads are experienced thereby pushing the transmission systems closer to their stability and thermal limits and hence, causing the transfer of reactive power during steady state operating conditions to constitute a major problem of voltage instability (Nkan et al, 2019b). The application of flexible alternating current transmission system (FACTS) devices to power system stability has been an attractive ongoing area of research (Archana, 2016), and in most of the reported studies, attention has been focused on the ability of these devices to improve voltage magnitude profiles (Tripathi and Pandiya, 2017), improve system security by damping system oscillations, enhancement of power system performance like transfer stability, secure voltage profile and reduce the system losses (Shishir et al, 2014). Minimal attempts have been made to investigate the effect of multiple FACTS installations in power system for reliability purpose. With the increasing need for higher exchange of electrical energy through existing transmission lines, grid companies are more interested in raising and controlling the power-flow through the main transmission lines without losing system reliability. Hence, transmission lines are expected to be operated at maximum capacity close to thermal limits (Lumpur, 2000). This results to some parts of the transmission line experiencing low and high power flow.

In (Pasala et al, 2012), shunt FACTS devices; SVC and Static Synchronous Compensator (STATCOM) were located on the transmission line to improve transient stability with predefined direction of real power flow using Simulink. The results show that the FACTS devices, when placed slightly offcentre towards sending-end, give better performance in improving system stability. However, these FACTS controllers were not optimally placed as the midpoint was only a guess work. Attia and Sharaf, (2020) in their work presented a FACTS based dynamic stabilization scheme using modified series-parallel switched filter compensation (MSPFC). The proposed dynamic scheme was controlled by an Incremental Fuzzy Logic controller (MIFLC) to ensure fast response dynamic voltage stabilization and efficient energy utilization. In enhancement of power system voltage stability with the aid of reactive/capacitive power switching mechanism, Folorunso et al, (2014) placed SVC in Owerri transmission station and the result showed the dynamic nature of the SVC in absorbing reactive power in period of high voltage and supplying reactive power when low voltage occurs. (Kavitha and Neela, 2017; Raj 
and Bhattacharyya, 2017) examined the effectiveness of the optimal installation of TCSC, SVC, combined TCSC-SVC and UPFC in upgrading the security of power systems, in terms of minimizing the line loading and load voltage deviations. In (Bhattacharyya and Kumar, 2016; Kumar et al, 2019), the authors applied gravitational search algorithm (GSA) based optimization technique for the optimal allocation of FACTS devices in IEEE 30 and 57 test bus systems. Both active and reactive loading of the power system was considered and the effect of FACTS devices on the power transfer capacity of the individual generator was investigated. (Dixit et al, 2015; Agrawal et al, 2018; Ahmad and Sirjani, 2020) presented the employment of different optimization techniques to optimally placed TCSC in the power system. Their findings resulted in the reduction of active power and transmission line losses. Hemeida et al, (2020) employed two-area system to examine the feasibility of TCSC, with auxiliary control to improve the grid voltage profile, and network performance. The simulation results proved the effectiveness of the proposed method for voltage profile improvement and network performance.

In this paper, effect of the multiple FACTS devices on voltage stability and power losses will be investigated in the Nigerian $330 \mathrm{kV}, 48$-bus system. SVC and TCSC will be optimally placed in the system using PSAT. The compensating effect when both devices are placed together in the system will be compared with the effect of the FACTS devices placed individually in the system.

\section{METHODOLOGY}

In this section, the models of the FACTS controllers under study are briefly reviewed and presented. Modeling of the Nigerian $330 \mathrm{kV}, 48$-bus power system network with the FACTS controllers is also achieved and presentation of the power system bus and transmission line data is made.

\section{A. Modeling of SVC AND TCSC}

Figure 1 demonstrates the SVC regulator model used in this study taking into consideration the firing angle $\alpha$, assuming a balanced basic frequency operation.

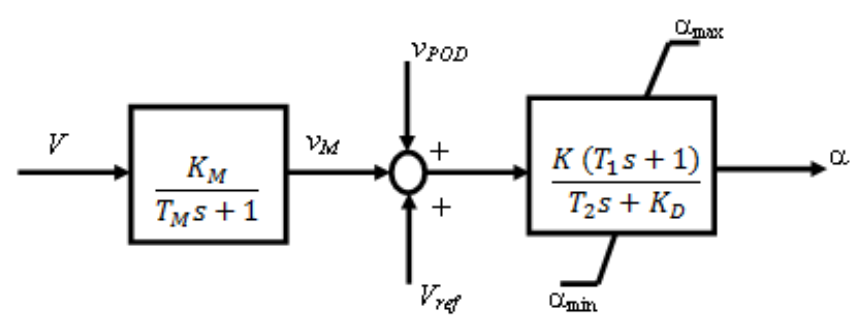

Figure. 1: SVC Regulator (Federico, 2008).

The algebraic and differential equations $(2.1-2.3)$, according to Federico, (2008) are as follows:

$$
\begin{aligned}
& \dot{V} M=\left(K_{m} V-v m\right) / T_{m} \\
& \dot{\alpha}=\left(-K_{D \alpha}+K \frac{T_{1}}{T_{2} T_{m}}\left(v m-K_{m} V\right)+K\left(V_{r e f}+v P O D-\right.\right. \\
& v m)) / T_{2}
\end{aligned}
$$

$$
Q=\frac{2 \alpha-\sin 2 \alpha-\pi\left(2-\frac{X_{C}}{X_{L}}\right)}{\pi X_{L}} V^{2}=b_{s v c}(\alpha) V^{2}
$$

where:

$\dot{V} \mathrm{M}$ is the measure voltage rating, $K_{m}$ is the measured gain, $V$ is the voltage rating, $v_{m}$ is the measured voltage, $\mathrm{T}_{\mathrm{m}}$ is the measured time delay, $\dot{\alpha}$ is the firing angle, $K_{D \alpha}$ is the integral deviation of the firing angle, $K$ is the regulator gain, $\mathrm{T}_{1}$ is the transient regulator time constant, $\mathrm{T}_{2}$ is the regulator time constant, $V_{\text {ref }}$ is the reference voltage, vPOD is the power oscillation damping voltage, $Q$ is the reactive power injected at the SVC node, $X_{L}$ is the inductive reactance, $X_{C}$ is the capacitive reactance and $b_{\mathrm{SVC}}$ is the total susceptance of the SVC.

The functional model of TCSC is represented in Figure 2 with the terminals of the controller at $T_{K}$ and $T_{M}$. The fundamental frequency operation can be represented by the following set of equations (4 - 15). These equations include the control system and sinusoidal currents equations in the controller (Hingorani and Gyugyi, 2000).

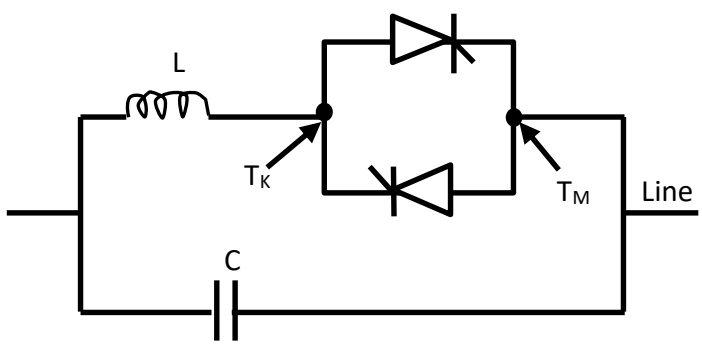

Figure 2: Thyristor Controlled Series Capacitor (Hingorani and Gyugyi, 2000).

$$
\begin{gathered}
{\left[x_{c}^{\prime}, \alpha^{\prime}\right]^{T}=f\left(x_{c}, \alpha, I, I_{r e f}\right)} \\
P+V_{k} V_{m} B_{e} \sin \left(\delta_{k}-\delta_{m}\right)=0 \\
-V_{k}^{2} B_{e}+V_{k} V_{m} B_{e} \cos \left(\delta_{k}-\delta_{m}\right)-Q_{k}=0 \\
-V_{m}^{2} B_{e}+V_{k} V_{m} B_{e} \cos \left(\delta_{k}-\delta_{m}\right)-Q_{m}=0 \\
B_{e}-B_{e}(\alpha)=0 \\
\left(P^{2}+Q_{k}^{2}\right)^{\frac{1}{2}}-I V_{k}=0
\end{gathered}
$$

where $x_{c}^{\prime}$ and $\mathrm{f}\left(x_{c}, \alpha, I, I_{r e f}\right)$ stand for the internal control system variables and equations. $x_{c}$ is the constant reactance of the TCSC model, $\alpha$ is the firing angle, $\mathrm{B}_{\mathrm{e}}$ is the series susceptance, $B_{r e f}$ is the reference susceptance, $V_{k}$ and $V_{m}$ are the terminal voltages of controller, $\delta_{k}$ and $\delta_{m}$ are the magnitudes of the angles at the controller terminals, $\mathrm{Q}_{\mathrm{k}}$ and $\mathrm{Q}_{\mathrm{m}}$ are the reactive power injections at both controller terminals, $\mathrm{P}$ and I are the active power and current flowing through the controller respectively, and $\mathrm{I}$ is the reference current of the controller (Hingorani and Gyugyi, 2000). $B_{e}$ is given as presented in Eq. (10). 
$B_{e}(\alpha)=\pi\left(K_{x}^{4}-2 K_{x}^{2}+1\right) \cos K_{x}(\pi-\alpha)+$ $\left[X_{C}\left(\pi K_{x}^{4} \cos K_{x}(\pi-\alpha)-\pi \cos \left(K_{x}-\alpha\right)-\right.\right.$ $2 K_{x}^{4} \alpha \cos K_{x}(\pi-\alpha)$

where

$k_{x}($ Percentage of compensation of TCSC $)=\left(\frac{X_{C}}{X_{L}}\right)^{\frac{1}{2}}$

For an impedance control model with no droop, which yields the simplest set of steady state equations from the numerical point of view, the power flow equations for the TCSC are

$$
\begin{gathered}
B_{e}-B_{r e f}=0 \\
P+V_{k} V_{m} B_{e} \sin \left(\delta_{k}-\delta_{m}\right)=0 \\
-V_{k}^{2} B_{e}+V_{k} V_{m} B_{e} \cos \left(\delta_{k}-\delta_{m}\right)-Q_{k}=0 \\
B_{e}-B_{e}(\alpha)=0 \\
\left(P^{2}+Q_{k}^{2}\right)^{\frac{1}{2}}-I V_{k}=0
\end{gathered}
$$

\section{B. Modeling of Nigerian 48-bus System}

Modeling of the Nigerian 48-bus system derived from the bus and transmission line data, comprises $16 \mathrm{PV}$ generators for load flow studies, 79 transmission lines and 32 load buses was achieved using PSAT software in MATLAB as shown in Figure 3. The bus data and transmission line input data of the Nigerian power system network were picked from (Umoh, 2018) but not displayed here due to space constraint.

\section{SIMULATION}

\section{A. Newton-Raphson Power Flow without FACTS Controllers}

The result of the power flow solution of network of Figure 3 without FACTS devices using Newton Raphson iteration method for power flow computation is as presented in Table 1. The simulation was completed in $0.156 \mathrm{~s}$ after 4 iterations with a maximum convergence error of $2.9437 \times 10^{-9}$ p.u. with active and reactive maximum power mismatches of $2.12 \times 10^{-13}$ p.u. and $4.01 \times 10^{-13}$ p.u. respectively. According to Ayodele et al (2016), acceptable voltage profile should be within $\pm 5 \%$ of the normal $330 \mathrm{kV}$ voltage magnitude profile equivalent to 1.0 p.u. Hence from Table 1 , it is noticed that the voltage profile for the unfortified system shows that the following buses have voltages below this acceptable range: 3(Kaduna) - 0.94822, 4(Kano) - 0.93852, 6(Makurdi) $0.94047,9(\mathrm{Jos})-0.9381,28$ (Ayede) -0.94829 and 31(Sakete) -0.94689 .

\section{B. Optimal Placement of FACTS Devices}

Table 2 shows the simulation result of the continuation power flow (CPF) which was completed in 2.0922 seconds with maximum loading parameter $\left(\lambda_{\max }\right)$ yielding 3.1887 . It is observed that buses 3(Kaduna), 4(Kano), 6(Makurdi), 9(Jos), 13(Osogbo), 22(Ugwuaji) and 28(Ayede) are found to be very weak buses with voltages well below 0.800 p.u.

\begin{tabular}{|c|c|c|c|c|c|}
\hline $\begin{array}{l}\text { Bus } \\
\text { No }\end{array}$ & $\begin{array}{l}\text { Bus } \\
\text { Name }\end{array}$ & $\begin{array}{l}\text { Voltage } \\
\text { (pu) }\end{array}$ & $\begin{array}{l}\text { Phase } \\
\text { Angle } \\
\text { (rad) }\end{array}$ & $\begin{array}{l}\text { Real } \\
\text { Power } \\
\text { (pu) }\end{array}$ & $\begin{array}{l}\text { Reactive } \\
\text { Power } \\
\text { (pu) }\end{array}$ \\
\hline 1 & Birnin Kebbi & 0.98989 & 0.12733 & -1 & -0.62 \\
\hline 2 & Kainji GS & 1.0 & 0.14101 & 4.92 & 0.50156 \\
\hline 3 & Kaduna & 0.94822 & -0.00196 & -1.2 & -0.9 \\
\hline 4 & Kano & 0.93852 & -0.0149 & -0.41 & -0.26 \\
\hline 5 & Asaba & 0.97449 & 0.03685 & -0.8 & -0.59 \\
\hline 6 & Makurdi & 0.94047 & -0.01068 & -1.0 & -0.6 \\
\hline 7 & Alagbon & 1.0225 & -0.01134 & -0.7 & -0.43 \\
\hline 8 & Lekki & 1.0146 & -0.01596 & -1.1 & -0.78 \\
\hline 9 & Jos & 0.9381 & -0.01536 & -1.6 & -0.7 \\
\hline 10 & Shiroro GS & 1.0 & 0.04631 & 5.0 & 6.3177 \\
\hline 11 & Jebba & 0.99552 & 0.09226 & -2.6 & -1.95 \\
\hline 12 & Jebba GS & 1.0 & 0.09623 & 4.03 & 3.77 \\
\hline 13 & Oshogbo & 0.9716 & 0.04773 & -1.27 & -0.95 \\
\hline 14 & Ganmo & 0.97467 & 0.06552 & -1.0 & -0.75 \\
\hline 15 & Katampe & 0.969 & 0.0382 & -3.03 & -2.27 \\
\hline 16 & Gwagwalada & 0.97132 & 0.03834 & -2.2 & -1.65 \\
\hline 17 & Lokoja & 0.97999 & 0.04126 & -1.2 & -0.9 \\
\hline 18 & Ajaokuta & 0.99934 & 0.08191 & -1.2 & -0.9 \\
\hline 19 & Geregu GS & 1.0 & 0.08321 & 5.31 & 2.0461 \\
\hline 20 & Odukpani GS & 1.0 & 0.08415 & 2.6 & 0.98022 \\
\hline 21 & New heaven & 0.97093 & 0.03608 & -1.96 & -1.47 \\
\hline 22 & Ugwuaji & 0.96702 & 0.031 & -1.75 & -1.31 \\
\hline 23 & Onitsha & 0.97343 & 0.03741 & -1.0 & -0.75 \\
\hline 24 & Benin & 0.99563 & 0.05622 & -1.44 & -1.08 \\
\hline 25 & Ihovbor GS & 1,0 & 0.06294 & 1.166 & 0.81105 \\
\hline 26 & Adiabor & 0.99378 & 0.07192 & -0.9 & -0.48 \\
\hline 27 & Omotosho GS & 1.006 & 0.04124 & 1.65 & 0.9512 \\
\hline 28 & Ayede & 0.94829 & 0.00364 & -1.9 & -1.51 \\
\hline 29 & Ikot Ekpene & 0.98185 & 0.04068 & -1.65 & -0.74 \\
\hline 30 & Olorunsogo GS & 0.97 & 0.01475 & 1.96 & -0.15072 \\
\hline 31 & Sakete & 0.94689 & -0.06526 & -2.25 & -1.9 \\
\hline 32 & Akangba & 0.99231 & -0.02395 & -2.03 & -1.52 \\
\hline 33 & Ikeja West & 0.99657 & -0.01956 & -8.47 & -6.35 \\
\hline 34 & Okearo & 1.0133 & -0.01106 & -1.2 & -0.9 \\
\hline 35 & Aja & 1.0278 & -0.00552 & -1.2 & -0.9 \\
\hline 36 & Egbin GS & 1.033 & 0.0 & 9.2005 & 17.6746 \\
\hline 37 & AES GS & 1.0 & 0.07664 & 2.452 & -1.2759 \\
\hline 38 & Okpai GS & 1.0 & 0.07442 & 4.66 & 2.6555 \\
\hline 39 & Sapele GS & 1.0 & 0.06584 & 1.78 & 0.92912 \\
\hline 40 & PH Main & 0.98741 & 0.0306 & -2.8 & -1.4 \\
\hline 41 & Delta GS & 1.003 & 0.07619 & 3.41 & 1.5599 \\
\hline 42 & Aladja & 0.99 & 0.06026 & -2.1 & -1.58 \\
\hline 43 & Itu & 0.98783 & 0.0109 & -1.99 & -0.91 \\
\hline 44 & Eket & 0.99188 & -0.0019 & -2.0 & -1.47 \\
\hline 45 & Ibom GS & 1.0 & -0.00188 & 0.305 & 2.2952 \\
\hline 46 & Alaoji & 0.99243 & 0.03697 & -2.4 & -1.0 \\
\hline 47 & Alaoji GS & 1.0 & 0.0895 & 2.5 & 0.1307 \\
\hline 48 & Afam GS & 1.0 & 0.04905 & 7.0 & 4.0565 \\
\hline
\end{tabular}

Validating the above result, voltage stability sensitivity factor (VSSF) was computed for all the load buses as shown in
Table 1: Power flow results of Nigerian 48-bus system without FACTS devices.

Table 3. VSSF is represented by $\left|d V_{i} / d P_{\text {total }}\right|$ where $d P_{\text {total }}$ and $d V_{i}$ are the total active load change and per unit voltage change in the $i^{\text {th }}$ bus in the system. The change in the total active load is always the same for the buses; hence, it can be taken to be the differential change in the bus voltages. The bus with the highest voltage sensitivity factor is always taken as the weakest bus in the system. The term weakest bus stems from the fact that the load that is connected to this bus will be more affected than other loads when there is an unexpected load increase (Keskin, 2007). It is noticed that bus 4 (Kano) has the highest sensitivity factor of 0.57724 closely followed by bus 3 (Kaduna) with 0.49777 . They are therefore adjudged the weakest buses for the installation of the two FACTS devices. 
Table 2: Continuation power flow results of the Nigerian 48-bus system.

\begin{tabular}{|c|c|c|c|c|c|}
\hline $\begin{array}{l}\text { Bus } \\
\text { No } \\
\end{array}$ & $\begin{array}{l}\text { Bus } \\
\text { Name } \\
\end{array}$ & $\begin{array}{c}\text { Voltage } \\
\text { (pu) }\end{array}$ & $\begin{array}{c}\text { Phase } \\
\text { Angle } \\
\text { (rad) }\end{array}$ & $\begin{array}{c}\text { Real } \\
\text { Power } \\
\text { (pu) }\end{array}$ & $\begin{array}{c}\text { Reactive } \\
\text { Power } \\
\text { (pu) }\end{array}$ \\
\hline 1 & Birnin Kebbi & 0.96707 & 1.4136 & -3.1179 & -1.9331 \\
\hline 2 & Kainji GS & 1.0 & 1.4573 & 15.3402 & 3.9795 \\
\hline 3 & Kaduna & 0.45045 & 0.91556 & -3.7415 & -2.8061 \\
\hline 4 & Kano & 0.36128 & 0.69314 & -1.2784 & -0.81066 \\
\hline 5 & Asaba & 0.82442 & 1.0825 & 0.0 & 0.0 \\
\hline 6 & Makurdi & 0.4527 & 0.84401 & -3.1179 & -1.8708 \\
\hline 7 & Alagbon & 0.99535 & -0.04016 & -2.1826 & -1.3407 \\
\hline 8 & Lekki & 0.96922 & -0.05571 & -3.4297 & -2.432 \\
\hline 9 & Jos & 0.45069 & 0.88936 & 0.0 & 0.0 \\
\hline 10 & Shiroro GS & 1.0 & 1.3216 & 15.5896 & 20.4486 \\
\hline 11 & Jebba & 0.95326 & 1.1445 & -8.1066 & -6.08 \\
\hline 12 & Jebba GS & 1.0 & 1.168 & 12.5652 & 19.449 \\
\hline 13 & Oshogbo & 0.76656 & 0.73986 & -3.9598 & -2.962 \\
\hline 14 & Ganmo & 0.82974 & 0.97765 & 0.0 & 0.0 \\
\hline 15 & Katampe & 0.9435 & 1.3103 & -9.4473 & -7.0777 \\
\hline 16 & Gwagwalada & 0.9562 & 1.3069 & 0.0 & 0.0 \\
\hline 17 & Lokoja & 0.97631 & 1.3106 & 0.0 & 0.0 \\
\hline 18 & Ajaokuta & 0.99566 & 1.3673 & -3.7415 & -2.8061 \\
\hline 19 & Geregu GS & 1.0 & 1.3754 & 16.5562 & 6.8176 \\
\hline 20 & Odukpani GS & 1.0 & 1.618 & 8.1066 & 3.8203 \\
\hline 21 & New heaven & 0.8002 & 1.2215 & -6.1111 & -4.5834 \\
\hline 22 & Ugwuaji & 0.79321 & 1.2334 & 0.0 & 0.0 \\
\hline 23 & Onitsha & 0.80527 & 1.2203 & -3.1179 & -2.3384 \\
\hline 24 & Benin & 0.89796 & 0.85171 & -4.4898 & -3.3674 \\
\hline 25 & Ihovbor GS & 1.0 & 0.85656 & 3.6355 & 16.0759 \\
\hline 26 & Adiabor & 0.97735 & 1.5797 & 0.0 & 0.0 \\
\hline 27 & Omotosho GS & 0.8155 & 0.52741 & 0.0 & 0.0 \\
\hline 28 & Ayede & 0.78631 & 0.25526 & -5.9241 & -4.7081 \\
\hline 29 & Ikot Ekpene & 0.9059 & 1.4184 & -5.1446 & -2.3073 \\
\hline 30 & Olorunsogo GS & 0.97 & 0.19153 & 6.1111 & 13.4839 \\
\hline 31 & Sakete & 0.88227 & -0.00628 & 0.0 & 0.0 \\
\hline 32 & Akangba & 0.85077 & -0.04229 & -6.3294 & -4.7392 \\
\hline 33 & Ikeja West & 0.88226 & -0.00628 & -26.4088 & -19.7988 \\
\hline 34 & Okearo & 0.95763 & -0.00289 & 0.0 & 0.0 \\
\hline 35 & Aja & 1.0129 & -0.02119 & 0.0 & 0.0 \\
\hline 36 & Egbin GS & 1.033 & 0.0 & 1.7733 & 54.9283 \\
\hline 37 & AES GS & 1.033 & 0.0 & 0.0 & 0.0 \\
\hline 38 & Okpai GS & 1.0 & 1.4938 & 14.5295 & 11.5664 \\
\hline 39 & Sapele GS & 0.93133 & 0.88685 & 0.0 & 0.0 \\
\hline 40 & PH Main & 0.95832 & 1.4402 & -8.7302 & -4.3651 \\
\hline 41 & Delta GS & 1.003 & 0.95292 & 10.6321 & 10.1301 \\
\hline 42 & Aladja & 0.9784 & 0.93175 & 0.0 & 0.0 \\
\hline 43 & Itu & 0.93086 & 1.3507 & -6.2047 & -2.8373 \\
\hline 44 & Eket & 0.94511 & 1.3057 & -6.2359 & -4.5834 \\
\hline 45 & Ibom GS & 1.0 & 1.3052 & 0.95097 & 7.7669 \\
\hline 46 & Alaoji & 0.94872 & 1.4417 & 0.0 & 0.0 \\
\hline 47 & Alaoji GS & 1.0 & 1.7846 & 7.7948 & 1.6201 \\
\hline 48 & Afam GS & 1.0 & 1.4995 & 21.8255 & 16.0121 \\
\hline
\end{tabular}

The P-V nose curves for the seven weak buses illustrated in Figure 4 affirms bus 4(Kano) and bus 3(Kaduna) as the weakest buses hence, most suitable for the placement of FACTS devices. This is because the reactive powers are insufficient at these load buses when the loading parameter reaches its critical point at 3.1887, causing an unstable power system and near-voltage collapse.

\section{Power Flow Simulation with FACTS Controllers}

With SVC installed at the weak buses 4(Kano), and 3 (Kaduna) of the case study system, the power flow simulation converges at $1.1727 \times 10^{-10}$ p.u. in 0.172 s after 4 iterations. Maximum real and reactive power mismatches are $1.94 \times$ $10^{-13}$ p.u. and 2.14250 p.u. respectively. With the placement
Table 3 Voltage stability sensitivity factors of the Nigerian 48-bus system.

\begin{tabular}{|c|c|c|c|c|c|}
\hline $\begin{array}{l}\text { Bus } \\
\text { No }\end{array}$ & Bus Name & $\begin{array}{c}\text { Voltage } \\
\text { Stability } \\
\text { Sensitivity } \\
\text { Factor }\end{array}$ & $\begin{array}{l}\text { Bus } \\
\text { No }\end{array}$ & Bus Name & $\begin{array}{c}\text { Voltage } \\
\text { Stability } \\
\text { Sensitivity } \\
\text { Factor }\end{array}$ \\
\hline 1 & Birnin Kebbi & 0.02282 & 25 & Ihovbor GS & 0.00000 \\
\hline 2 & Kainji GS & 0.00000 & 26 & Adiabor & 0.01643 \\
\hline 3 & Kaduna & 0.49777 & 27 & Omotosho GS & 0.00000 \\
\hline 4 & Kano & 0.57724 & 28 & Ayede & 0.16198 \\
\hline 5 & Asaba & 0.15007 & 29 & Ikot Ekpene & 0.07595 \\
\hline 6 & Makurdi & 0.48777 & 30 & Olorunsogo GS & 0.00000 \\
\hline 7 & Alagbon & 0.02715 & 31 & Sakete & 0.06462 \\
\hline 8 & Lekki & 0.04538 & 32 & Akangba & 0.14154 \\
\hline 9 & Jos & 0.48741 & 33 & Ikeja West & 0.11431 \\
\hline 10 & Shiroro GS & 0.00000 & 34 & Okearo & 0.05367 \\
\hline 11 & Jebba & 0.04226 & 35 & Aja & 0.01490 \\
\hline 12 & Jebba GS & 0.00000 & 36 & Egbin GS & 0.00000 \\
\hline 13 & Oshogbo & 0.20504 & 37 & AES GS & 0.00000 \\
\hline 14 & Ganmo & 0.14493 & 38 & Okpai GS & 0.00000 \\
\hline 15 & Katampe & 0.02550 & 39 & Sapele GS & 0.00000 \\
\hline 16 & Gwagwalada & 0.01512 & 40 & PH Main & 0.02909 \\
\hline 17 & Lokoja & 0.00368 & 41 & Delta GS & 0.00000 \\
\hline 18 & Ajaokuta & 0.00368 & 42 & Aladja & 0.01160 \\
\hline 19 & Geregu GS & 0.00000 & 43 & Itu & 0.05697 \\
\hline 20 & Odukpani GS & 0.00000 & 44 & Eket & 0.04677 \\
\hline 21 & New heaven & 0.17073 & 45 & Ibom GS & 0.00000 \\
\hline 22 & Ugwuaji & 0.17381 & 46 & Alaoji & 0.04371 \\
\hline 23 & Onitsha & 0.16816 & 47 & Alaoji GS & 0.00000 \\
\hline 24 & Benin & 0.09767 & 48 & Afam GS & 0.00000 \\
\hline
\end{tabular}

of TCSC on line 3 - 4 and on line 3 - 9 closer to the weakest bus, simulation is completed in 0.1715 after

4 iterations with a maximum convergence error of $9.6232 \times$ $10^{-11}$ with active and reactive maximum power mismatches of 1.07678 p.u. and 1.06881 p.u. respectively.

Lastly, SVC and TCSC are placed in the case study network for effective enhancement of power system stability. The series FACTS device (TCSC) is placed on line 3-9 closer to bus 3 while the shunt FACTS device (SVC) is placed on bus 4. Performance of power flow on the system shows that in $0.281 \mathrm{~s}$, the simulation reaches its convergence after 4 iteration at $8.4746 \times 10^{-11}$ p.u., with maximum real and reactive power mismatches of 1.25750 p.u. and 0.42352 p.u. respectively.

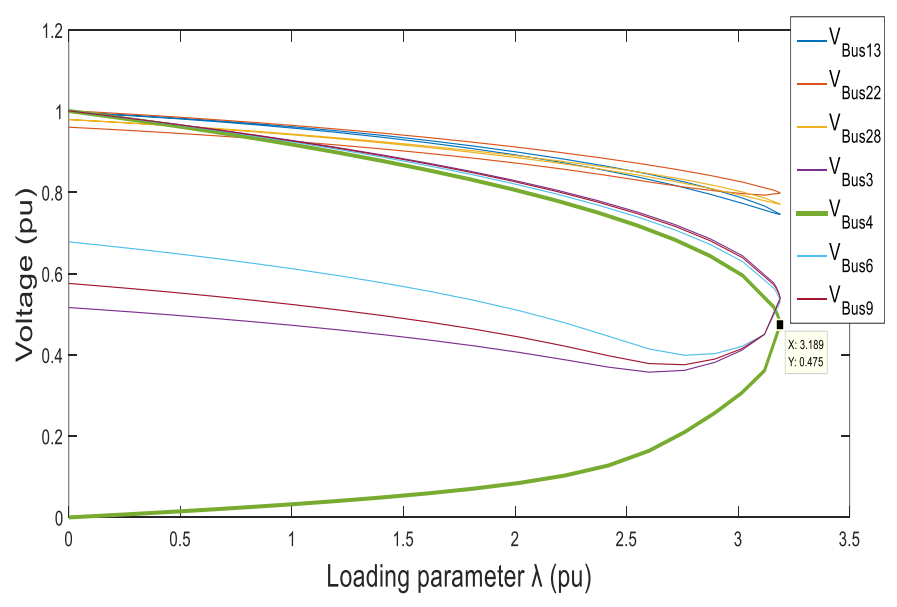

Figure 4: Voltage P-V nose curves for seven low voltage buses. 


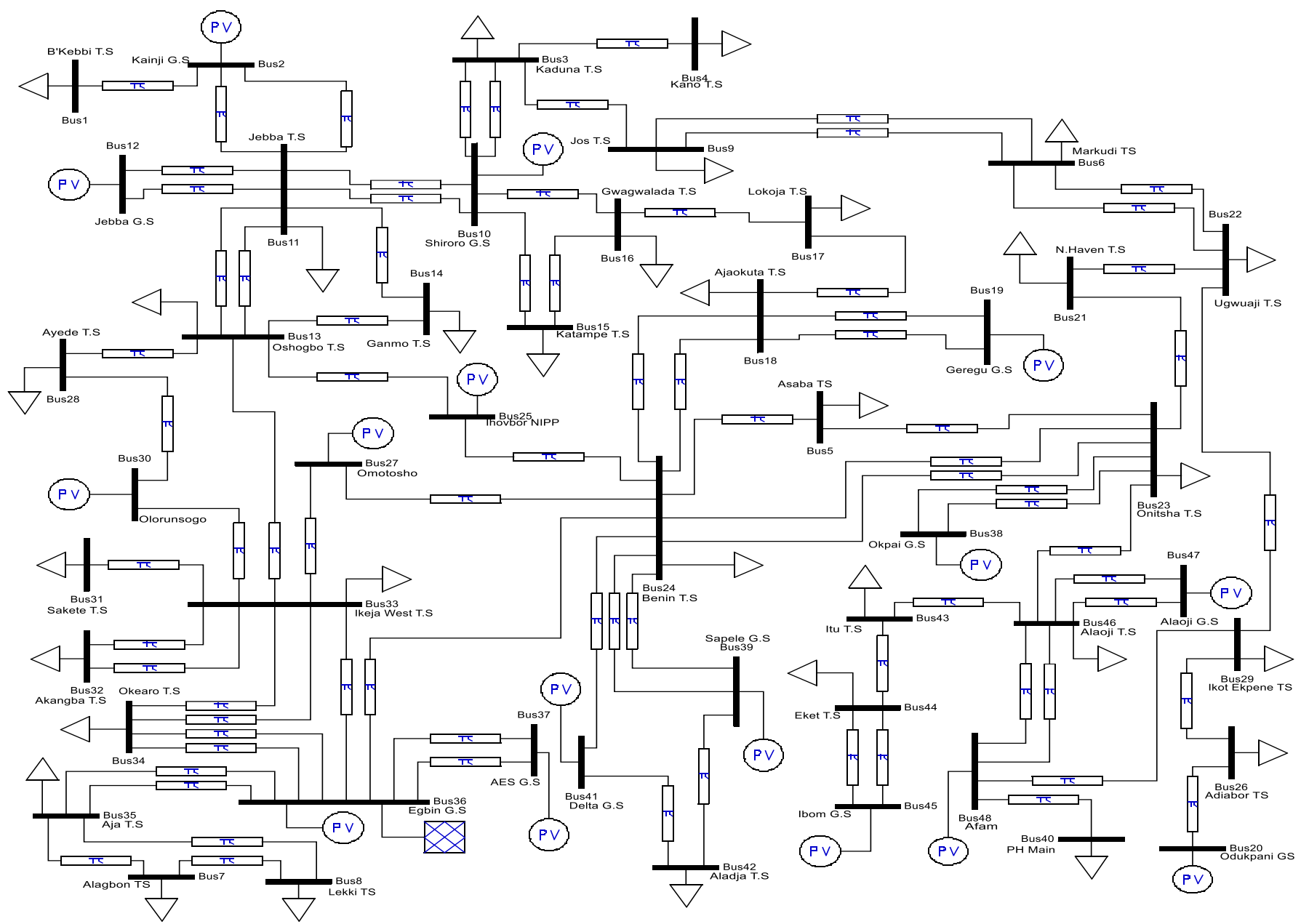

Figure 3: Nigerian 48-bus system.

\section{SIMULATION RESULTS AND DISCUSSION}

The results of the power flow summarized in Table 4 and the voltage magnitude profile graphically represented in Figure 5 show that for the unfortified case system, simulation results show that the total real power generation in p.u. stood at 57.94345 while the reactive power was 43.25271 p.u. The total real power load of the system was 57.35 p.u., and the reactive power of the load was 39.52 p.u. It was also found out that the total real power losses in p.u. was 0.59345 while the reactive power losses was 3.73251 p.u. SVC, which is a shuntconnected device of fixed capacitance in parallel with a thyristor controlled reactor helps to maintain acceptable voltage profile by supplying reactive power in the capacitive mode.

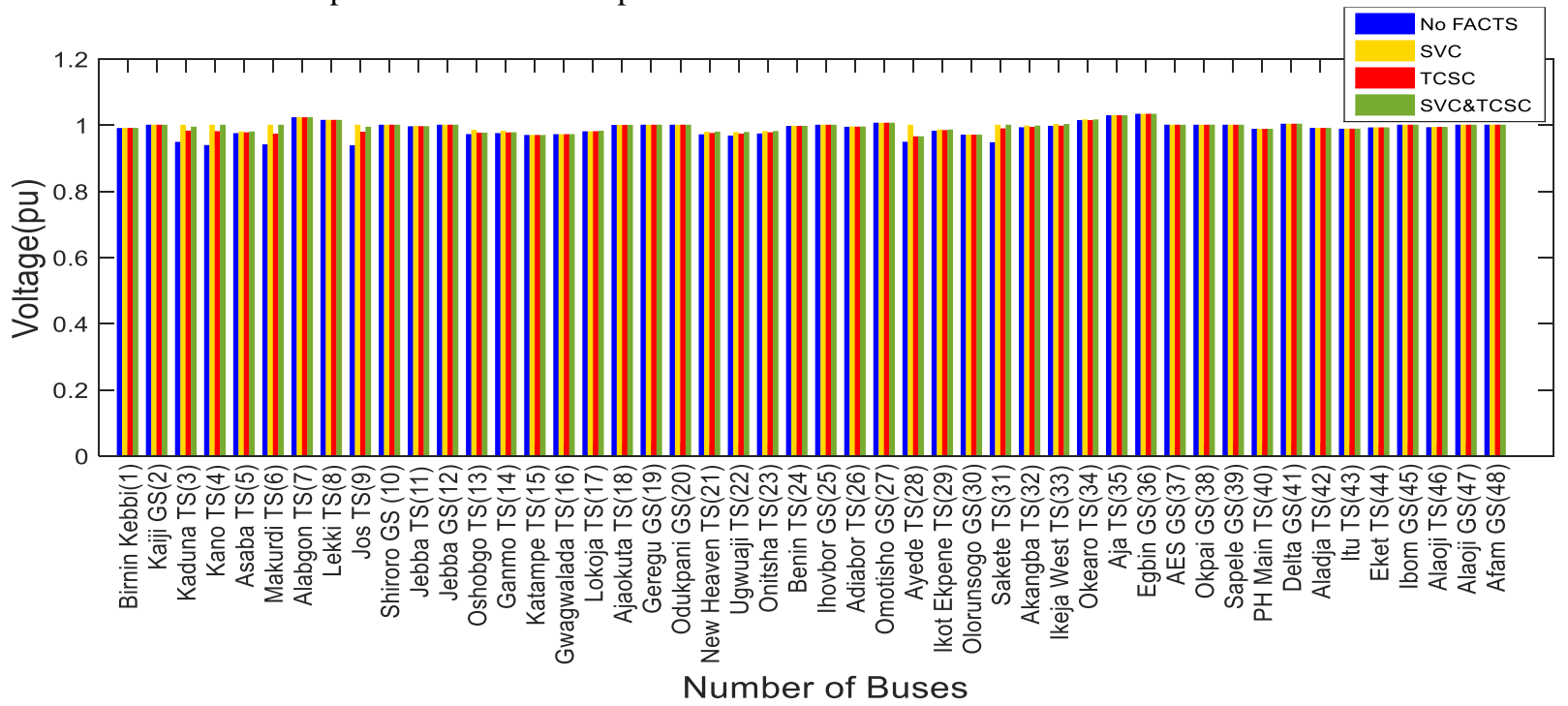

Figure 5: Voltage profile without FACTS, with SVC, TCSC and combined SVC\&TCSC. 
Table 4: Voltage profile (p.u.) and power details without and with FACTS devices.

\begin{tabular}{|c|c|c|c|c|c|}
\hline $\begin{array}{l}\text { Bus } \\
\text { No }\end{array}$ & Bus Name & $\begin{array}{c}\text { No } \\
\text { FACTS }\end{array}$ & $\begin{array}{l}\text { With } \\
\text { SVC }\end{array}$ & $\begin{array}{l}\text { With } \\
\text { TCSC }\end{array}$ & $\begin{array}{c}\text { With } \\
\text { SVC } \\
\text { \& TCSC }\end{array}$ \\
\hline 1 & Birnin Kebbi & 0.98989 & 0.98989 & 0.98989 & 0.98989 \\
\hline 2 & Kainji GS & 1.0 & 1.0 & 1.0 & 1.0 \\
\hline 3 & Kaduna & 0.94822 & 1.0 & 0.98206 & 0.99405 \\
\hline 4 & Kano & 0.93852 & 1.0 & 0.98046 & 1.0 \\
\hline 5 & Asaba & 0.97450 & 0.97951 & 0.97708 & 0.97962 \\
\hline 6 & Makurdi & 0.94047 & 1.0 & 0.97278 & 1.0 \\
\hline 7 & Alagbon & 1.02247 & 1.0225 & 1.02247 & 1.0225 \\
\hline 8 & Lekki & 1.01456 & 1.0146 & 1.01456 & 1.0146 \\
\hline 9 & Jos & 0.93810 & 1.0 & 0.97884 & 0.99387 \\
\hline 10 & Shiroro GS & 1.0 & 1.0 & 1.0 & 1.0 \\
\hline 11 & Jebba & 0.99522 & 0.9961 & 0.99550 & 0.99553 \\
\hline 12 & Jebba GS & 1.0 & 1.0 & 1.0 & 1.0 \\
\hline 13 & Oshogbo & 0.97160 & 0.98383 & 0.97547 & 0.97603 \\
\hline 14 & Ganmo & 0.97467 & 0.98107 & 0.97676 & 0.97712 \\
\hline 15 & Katamkpe & 0.969 & 0.96901 & 0.96898 & 0.96893 \\
\hline 16 & Gwagwalada & 0.97132 & 0.97131 & 0.97136 & 0.97142 \\
\hline 17 & Lokoja & 0.98 & 0.97986 & 0.98038 & 0.98096 \\
\hline 18 & Ajaokuta & 0.99934 & 0.99934 & 0.99935 & 0.99961 \\
\hline 19 & Geregu GS & 1.0 & 1.0 & 1.0 & 1.0 \\
\hline 20 & Odukpani GS & 1.0 & 1.0 & 1.0 & 1.0 \\
\hline 21 & New heaven & 0.97093 & 0.97872 & 0.97496 & 0.97893 \\
\hline 22 & Ugwuaji & 0.96702 & 0.97763 & 0.97248 & 0.97787 \\
\hline 23 & Onitsha & 0.97343 & 0.98059 & 0.97709 & 0.9807 \\
\hline 24 & Benin & 0.99563 & 0.99658 & 0.99612 & 0.99662 \\
\hline 25 & Ihovbor & 1.0 & 1.0 & 1.0 & 1.0 \\
\hline 26 & Adiabor & 0.99378 & 0.9945 & 0.99415 & 0.99452 \\
\hline 27 & Omotosho GS & 1.006 & 1.006 & 1.006 & 1.006 \\
\hline 28 & Ayede & 0.94829 & 1.0 & 0.96482 & 0.96489 \\
\hline 29 & Ikotekpene & 0.98185 & 0.98533 & 0.98364 & 0.9854 \\
\hline 30 & Olorunsogo GS & 0.97 & 0.97 & 0.97 & 0.97 \\
\hline 31 & Sakete & 0.94689 & 1.0 & 0.98883 & 1.0 \\
\hline 32 & Akangba & 0.99231 & 0.99762 & 0.9928 & 0.99741 \\
\hline 33 & Ikeja West & 0.99657 & 1.0019 & 0.99705 & 1.0016 \\
\hline 34 & Okearo & 1.01333 & 1.016 & 1.01358 & 1.0159 \\
\hline 35 & Aja & 1.02783 & 1.0278 & 1.02783 & 1.0278 \\
\hline 36 & Egbin GS & 1.033 & 1.033 & 1.033 & 1.033 \\
\hline 37 & AES GS & 1.0 & 1.0 & 1.0 & 1.0 \\
\hline 38 & Okpai GS & 1.0 & 1.0 & 1.0 & 1.0 \\
\hline 39 & Sapele GS & 1.0 & 1.0 & 1.0 & 1.0 \\
\hline 40 & PH Main & 0.98741 & 0.98741 & 0.98741 & 0.98741 \\
\hline 41 & Delta GS & 1.003 & 1.003 & 1.003 & 1.003 \\
\hline 42 & Aladja & 0.99 & 0.99 & 0.99 & 0.99 \\
\hline 43 & Itu & 0.98783 & 0.98808 & 0.98796 & 0.98808 \\
\hline 44 & Eket & 0.99188 & 0.99196 & 0.99192 & 0.99196 \\
\hline 45 & Ibom GS & 1.0 & 1.0 & 1.0 & 1.0 \\
\hline 46 & Alaoji & 0.99243 & 0.99284 & 0.99264 & 0.99285 \\
\hline 47 & Alaoji GS & 1.0 & 1.0 & 1.0 & 1.0 \\
\hline 48 & Afam GS & 1.0 & 1.0 & 1.0 & 1.0 \\
\hline \multicolumn{2}{|c|}{ Generated real power } & 57.94345 & 57.88503 & 57.83732 & 57.83996 \\
\hline \multicolumn{2}{|c|}{ Generated reactive power } & 43.25271 & 42.88223 & 42.76825 & 42.71227 \\
\hline \multicolumn{2}{|c|}{ Real power load } & 57.35 & 57.35 & 57.35 & 57.35 \\
\hline \multicolumn{2}{|c|}{ Reactive power load } & 39.52 & 39.52 & 39.52 & 39.52 \\
\hline \multicolumn{2}{|c|}{ Real power losses } & 0.59345 & 0.53503 & 0.48732 & 0.48996 \\
\hline \multicolumn{2}{|c|}{ Reactive power losses } & 3.73271 & 3.36223 & 3.24825 & 3.19227 \\
\hline \multicolumn{2}{|c|}{$\%$ Decrease of active } & & 9.844 & 17.884 & 17.439 \\
\hline \multicolumn{2}{|c|}{$\%$ Decrease of reactive } & & 9.925 & 12.979 & 14.478 \\
\hline \multirow{2}{*}{\multicolumn{2}{|c|}{$\begin{array}{l}\text { Total \% decrease of active } \\
\text { and reactive power losses }\end{array}$}} & & & & \\
\hline & & & 19.769 & 30.863 & 31.917 \\
\hline
\end{tabular}

In this process, the total transmission line reactance is reduced while the voltage across the impedance is increased, leading to the increase in the line currents and transmitted power. Therefore, it can be noticed from the simulation that the voltage magnitude profiles with the system fortified using SVC compared with the uncompensated network are improved. The real and reactive power generated by the system are 57.88503 p.u. and 42.88223 p.u. while the real and reactive power losses reduced from 0.59345 p.u. and 3.73271 p.u. to 0.53503 p.u. and 3.36223 p.u. giving $9.844 \%$ decrease and $9.925 \%$ decrease, all, respectively. The voltage profiles of the affected buses are duly compensated and raised up to $\pm 5 \%$ of the acceptable value.

Functioning in its capacitive boost mode, simulation results show that TCSC, which consists of compensating capacitor, bypass inductor, and thyristors, operates by absorbing energy and reducing short circuit current through the inductor connected in series with the bidirectional thyristors. The capacitor discharge current pulse will circulate through the parallel inductive branch, releasing its reactance in series with the transmission lines which result in increase in loading capability of the transmission line. The total real and reactive power generation for the system with TCSC are 57.83732 p.u. and 42.76825 p.u. respectively, while the real and reactive power losses are reduced to 0.48732 p.u. and 3.24825 p.u. respectively giving $17.884 \%$ decrease and $12.979 \%$ decrease, all, respectively. For the combination of SVC and TCSC in the power system network, simulation results clearly show that the voltage magnitude profile of the weak buses is adequately improved through the shunt connected SVC device which function to increase the voltage across the impedance of the transmission line.

The TCSC on the other hand enhances the loadability of the line by releasing its reactance in series with the line through its discharged current pulse. The reduction in the real and reactive power losses from 0.59345 p.u. and 3.73271 p.u. respectively to 0.48996 p.u. and 3.19227 p.u. respectively, resulting to $17.439 \%$ decrease for real power losses and $14.478 \%$ decrease for reactive power losses, shows a tremendous improvement in power transfer capabilities of the combination of these FACTS devices.

Summary of the active and reactive power losses of all the four scenarios as tabulated in Table 4. The total percentage decrease in the active and reactive power losses are also illustrated in the table where the combination of SVC and TCSC is seen to have the highest total loss reduction of $31.917 \%$ closely followed by TCSC with $30.869 \%$ and SVC with $19.769 \%$. This shows that the combination enhances power transfer capability and hence, systems stability.

\section{CONCLUSION}

Effects of multiple FACTS controllers in the Nigerian 48bus system have been investigated with the optimal installation of SVC, TCSC and the combination of SVC and TCSC. Results of bus voltage magnitude profiles, transmission lines real and reactive power losses without and with FACTS devices have been compared in the event of small disturbances like voltage drops because of long transmission lines and variation in loads. The FACTS devices showed sterling power transfer capabilities through stability enhancement by restoring the voltage magnitude profiles at the buses which had experienced voltage dips back to the acceptable value of $\pm 5 \%$ of $330 \mathrm{kV}(0.95$ p.u -1.05 p.u of 1.0 p.u $)$ and mitigating against 
both real and reactive power losses in the system. Of the three scenarios of the controllers' applications, the combination of SVC and TCSC FACTS devices gave a better compensation for effective steady state stability of the Nigerian 48-bus system compared to stand alone SVC or TCSC. This was seen in their ability to curb excessive power losses by reducing total real and reactive power losses by $31.917 \%$ compared to that of SVC which was $30.863 \%$ and that of TCSC which was $19.769 \%$.

\section{REFERENCES}

Agrawal, R.; S. K. Bharadwaj; and D. P. Kothari. (2018). Population based evolutionary optimization techniques for optimal allocation and sizing of thyristor controlled series capacitor. Journal of Electrical Systems and Information Technology, 5(3): 484-501.

Ahmad, A. A. and Sirjani, R. (2020). Optimal placement and sizing of multi-type FACTS devices in power systems using metaheuristic optimization techniques: An updated review. Ain Shams Engineering Journal, 11: 611-628.

Archana, N. V. (2016). Adaptive controllers strategies for FACTS devices in a power system to enhance stability. PET Research centre, PESCE, Mandya. Available online at: http//hdl.handle.net/10603/76655. Accessed on March 24, 2020.

Attia, A. F. and Sharaf, A. M. (2020). A robust FACTS based fuzzy control scheme for dynamic stabilization of generator station. Ain Shams Engineering Journal, 11: 629641.

Ayodele, T. R.; A. S. Ogunjuyigbe; and O. O. Oladele. (2016). Improving the transient stability of Nigerian $330 \mathrm{kV}$ transmission network using static var compensation part 1: the base study. Nigerian Journal of Technology (NIJOTECH), 35(1): 155-166.

Bhattacharyya, B. and Kumar, S. (2016). Loadability enhancement with FACTS devices using gravitational search algorithm. International Journal of Electrical Power and Energy Systems, 78: 470-479.

Dixit, S.; L. Srivastava; A. Singh; and G. Agnihotri. (2015). Optimal placement of TCSC for enhancement of power system stability using heuristic methods: An overview. International Journal of Hybrid Information Technology, 8(6): 367-374.

Federico, M. (2008). Documentation for power system analysis toolbox version 2.0.0. Castilla-La Mancha, Ciudad Real, Spain.

Folorunso, O.; C. C. Osuji; and O. S. Ighodalo. (2014). Enhancement of power system voltage stability with the aid of reactive/capacitive power switching mechanism: (a case study of Owerri transmission company of Nigeria). Journal of Advancement in Engineering and Technology, 2(1): 1-6.

Hemeida, A. M.; M. M. Hamada; Y. A. Mobarak; A. ElBahnasawy; M. G. Ashmawy; and T. Senjyu. (2020). TCSC with auxiliary controls based voltage and reactive power controls on grid power system. Ain Shams Engineering Journal, 11: 587-609.

Hingorani, N. G. and Gyugyi, L. (2000). Understanding FACTS, concepts \& technology of flexible AC transmission systems, Wiley-IEEE Press.

Kavitha, K. and Neela, R. (2017). Optimal allocation of multi-type FACTS devices and its effect in enhancing system security using BBO, WIPSO \& PSO. Journal of Electrical Systems and Information Technology, 5(3): 777-793.

Keskin, M. B. (2007). Continuation power flow and voltage stability of power systems. A Thesis submitted to the Graduate School of Natural and Applied Science of Middle East Technical University. 23-41.

Kumar, L.; S. Kumar; S. K. Gupta; and B. K. Raw. (2019). Optimal location of FACTS devices for loadability enhancement using gravitational search algorithm. Paper presented at 5th International Conference for Convergence in Technology (I2CT), Bombay, India, 1-5.

Lumpur, K. (2000). TENCON Proceedings. Intelligent Systems and Technologies for the New Millennium, Renaissance-New World Hotel, Kuala Lumpur, Malaysia, 24th-27th September 2000Cat. No.00CH37119), 1-25.

Nkan, I. E.; O. I. Okoro; C. C. Awah; and U. B. Akuru. (2019a). Investigating the dynamic stability of the Nigerian 48bus systems for improved system performance using FACTS. Paper presented at 27th African International Domestic Use of Energy (DUE) Conference, Wellington, South Africa, 34-42.

Nkan, I. E.; O. I. Okoro; C. C. Awah; and U. B. Akuru. (2019b). Investigating the steady state stability of the Nigerian 48-bus system using FACTS devices. Nigerian Journal of Technology (NIJOTECH), 38(3): 732-743.

Pasala, G.; I. P. Reddy; and P. S. Hari. (2012). Shunt FACTS devices for first-swing stability enhancement in interarea power system. IET Chennai Third International Conference on Suitable Energy and Intelligent System (SEISCON), Tiruchengode, 1-7.

Raj, S.; and B. Bhattacharyya. (2017). Optimal placement of TCSC and SVC for reactive power planning using whale optimization algorithm. Swarm Evol Comput, 40: 131-143.

Shishir, D.; A. Ganga; S. Laxmi; and S. Ankite. (2014). An overview of placement of TCSC for enhancement of power system stability. Paper presented at Sixth International Conference on Computational Intelligence and Communication Networks, Bhopai, 1184-1187.

Tripathi, P. and Pandiya, G. P. (2017). A Survey on the impact of FACTS controllers on power system performance. International Journal of Engineering Trends and Technology (IJETT), 46(1): 24-28.

Umoh, E. C. (2018). Top of the hour maximum power flow of the grid $330 \mathrm{kV}$ daily load flow. National Control Centre, Oshogbo (Transmission Company of Nigeria). 